\title{
14 The voice of the voiceless? Decoloniality and online radical discourses in South Africa
}

\author{
Lorenzo Dalvit
}

\section{Introduction}

South Africa has one of the highest internet penetration rates on the African continent. Because of its history of political struggle, it has a vibrant civil society and a robust public debate. However, recent protests suggest that for a large portion of the population, public violence is still seen as an effective way to put issues on the national agenda. Digital media promises to revolutionise public debate by giving a "voice to the voiceless". By problematising which voices, who are the voiceless and why this is the case, this chapter problematises digital media and opens the discussion around the emergence of truly alternative voices and viewpoints. The nature of radical discourses within the digital public sphere is explored in relation to contentious issues rooted in historical processes, such as rape and farm murders. The approach is a decolonial one, concerned with bringing to light and interrogating the relations of power and cultural domination at play in constructing radical externality.

\section{Coloniality in South Africa}

South Africa combines one of the strongest economies on the African continent with one of the most unequal societies in the world. The country is still, to a large extent, shaped by Apartheid, which could be described as a form of colonialism (see Mbembe, 2001). Its legacy lingers on in what Quijano (2000) calls coloniality, expressed through coloniality of power, being and knowledge. Coloniality of power can be defined as the persistent form of discrimination and hegemonic domination inherited from the colonial system into subsequent social orders. Physical violence against members of marginalised groups provides countless examples, ranging from police brutality (Bruce, 2002) to violent crime (Demombynes and Özler, 2002) and domestic abuse (Jewkes, Levin and Penn-Kekana, 2002). A more subtle form of coloniality of power is expressed through structural violence (Christie, Wagner and Winter, 2001). A white privilege persists and "modern" ways of being are enforced through formal systems such as education (Soudien, 2010; Swartz, Arogundade and Davis, 2014) and through the increasing pervasiveness of datafication (see Arora, 2016).

DOI: $10.4324 / 9781003111962-14$ 
Coloniality of being refers to the systems of hierarchies between different ways of being in the world. The colonial encounter created the conditions to build on and extend patriarchal gender relationships to other attributes, first and foremost, race in the service of exploitation (Maldonado-Torres, 2007). The ability to categorise such socially constructed attributes and classify people accordingly is the quintessential mechanism of coloniality of being. Under Apartheid, such mechanism took the form of racial classification to support racial domination. In post-apartheid South Africa, racial and, to a lesser extent, gender classification persists with the intent to enable the redress of past injustices but, as warned against by Mignolo (2007), such redress appears to advantage a Black elite rather than the majority of the Black population (see Horwitz and Jain, 2011). As an example, at the time of writing, the COVID-19 pandemic is exposing deep structural inequalities in South African society and exacerbating the harsh living conditions of the most vulnerable portion of the population (see Graham, 2020; Manderson and Levine, 2020).

Coloniality of knowledge reflects the attribution of authoritative knowledge production to the metropole and of passive consumption to the periphery. As in other forms of coloniality, the goal is subordination and exploitation rather than annihilation, as exemplified by the harvesting of Indigenous knowledge about medicinal plants by the pharmaceutical industry (Mignolo, 2007; see also Green, 2012). In South Africa, coloniality of knowledge came into sharp focus during recent student protests calling for the decolonisation of the curriculum (Ndlovu, 2018). In the media, coloniality of knowledge is intimately linked with representation and voice (Chiumbu, 2016). Traditional media is often complicit in the cognitive injustice of representing members of marginalised groups as backward, irrational or unproductive (see Santos, 2012).

\section{Digital media and emancipation/liberation}

A decolonial perspective differentiates between emancipation and liberation. Mignolo (2007) defines the former as the efforts by members of local elites to contest hegemonic structures, but without challenging their terms of reference. According to Mignolo (2011), liberation can only be achieved through decoloniality as an analytical project, i.e. an act of epistemic disobedience challenging the very terms of reference imposed by modernity. Dahlberg (2007) notes how modern conceptions of online democracy are caught in a paradox of enabling freedom of expression while policing the boundaries of such freedom. He argues that an agonistic model of the digital public sphere accommodates the possibility of discursive radicalism, i.e. 'a systemic antagonism blocking the suturing of meaning, including the defining of 'legitimate' public sphere boundaries, and points to the possibility for successful contestation and re-articulation of discourse' (Dahlberg, 2007:54). The "radical" represents the irrational, extreme and absent 
"other" which cannot be given its own voice and serves to validate the dialectic between dominant and subordinate discourses. It also introduces a dynamic element by progressively pushing the boundaries of the digital public sphere, transforming it and radicalising it in the process. In this sense, the "radical" can be compared to the "constructively absent" postulated by de Sousa Santos (2012). However, in order to be epistemically disobedient in a decolonial sense, the goals of liberatory analysis are '(to detach) from [the modern] overall structure of knowledge in order to engage in an epistemic reconstitution' (E-International Relations, 2017:2). It is important to note that such analysis, while recognising and refuting canonical terms of reference as its starting point, does not entail a wholesale rejection of existing human knowledge, albeit produced in the West.

Globally, the promise by digital media to push the boundaries of public participation and give everybody a voice has been put under scrutiny. Morozov (2011) notes how repressive governments use the internet to spin propaganda, track activists and provide a way for their population to vent their frustration while preserving the status quo. Dean (2005) argues that democratic practices have been captured by the capitalist logic underpinning social media platforms, e.g. by reducing messages to contributions and by trapping users in endless arguments with no possibility of resolution in order to sustain the flow of data. While removing gatekeepers and allowing direct interaction between African politicians and their constituencies (Akinbobola, 2015), digital media has not freed democratic participation from the logics of accumulation, majoritarianism, expediency, etc. which constitute the "dark side" of modernity in the political domain. Emancipatory voices among the South African middle class saw in the internet an avenue to express their dissatisfaction (Glenn and Mettes, 2011). While these constituencies enjoy considerable economic power and cultural influence, their progressive potential is thwarted by their relatively small numbers at the ballot box compared to the rest of the population. As noted by Willems (2012), in many post-colonial societies anti-colonial movements continue, to a large extent, to perform the function of those civil society organisations that the disenfranchised masses do not have access to. Within the modern democratic dispensation, the ruling African National Congress (ANC) represents at the same time the state while exerting its influence on a significant portion of its natural counterpart, i.e. civil society. This may help to explain the apparent paradox of widespread criticism by township and rural dwellers of the political party they repeatedly voted into power. At the same time, for many middle and working class South Africans political participation (online and otherwise) is reduced to spectacle or ritual (e.g. sharing "thumbies", i.e. images of one's thumb tinted by the black ink used to avoid multiple voting during elections) on social media (see Chunylall, 2016).

Digital and mobile media provide new avenues for the perspectives, experiences and practices of members of marginalised groups to come to the fore (Wasserman, 2011). At the same time, the inequalities which characterise 
South African society are reflected online. While approximately $64 \%$ of the population is connected to the internet, this is largely due to widespread mobile penetration (Statista, 2020). For most South Africans from a marginalised background, the online experience is often mobile-first, mobile-centric and mobile-only (see Walton and Leukes, 2013). In a country characterised by endemic poverty, where a large portion of the population relies on social grants as its main source of income, this presents particular constraints. The possibility to participate online in public discussion, while nominally high, is in actual fact limited by the cost of data and network coverage. Research suggests that online interactions for a wide portion of the population take place via instant messaging, which is seen as a cheap alternative to voice calls and SMS (We are Social, 2019). Active participation on social media platforms such as Facebook and Twitter, while one of the highest on the continent, is at approximately $42 \%$ and $19 \%$ respectively (Statcounter, 2020). Adding to the fragmentation of the online public sphere is linguistic diversity coupled with relatively low levels of English proficiency (see Salawu, 2018).

\section{The pursuit of a radical voice online}

From the methodological point of view, the analysis of discourse from a decolonial perspective presents a number of challenges. Resende (2018) notes the colonial influence of scholars such as Faircloth and Foucault on scholarship in the field. She argues for decolonisation at the level of theory and method, problematising the supposed universality of knowledge and appraising local epistemological creativity. In particular, she puts forward an argument for 'decolonizing the being, making strategic use of this paradoxical space, which contains the possibilities of knowledge communion, also including common knowledge' (Resende, 2018:1). The researcher is required to distance him- or herself from a universal conception of "truth" and reflexively interrogate its collective historical construction within the subordinated condition of pain and suffering resulting from coloniality (see Passada, 2019). In this chapter, I focus on online discourses as epistemological potential in terms of gender and sexuality as well as race and class.

Consistent with a decolonial approach, I seek to avoid extractive methodologies (see Santos, 2016) as much as possible. I rely on freely available online publications and, when accessible, user comments. While it could be argued that social media material is by its very nature extractive and exploitative (see dean, 2005; Couldry and Mejias, 2019), I rely on such material in so far as it can be freely accessed online without the need to register or subscribe to any platform. This excludes some potentially relevant content on Facebook or WhatsApp but leaves major forums such as those on Twitter and YouTube open. It should be noted that these are still relatively elite platforms (see Dlamini et al., 2018), as is the consumption of online publications, which inevitably introduces a first bias as to who the "voiceless" 
are. A second and interrelated bias is represented by limiting my analysis to content in English. Despite the dominant role of English, South Africa's multilingual character is reflected online (Salawu, 2018). Precisely because of its crucial importance, a comparative analysis including speakers of different languages deserves a separate and dedicated publication by authors fully proficient in such languages.

\section{Gender and sexuality}

South Africa is characterised by high levels of rape and of gender-based violence. Buiten and Naidoo (2016) highlight the relationship between these and race, class and other socio-economic factors, as well as their historical roots. Gender inequalities are recognised as a key area by policy makers (Meyiwa, Williamson, Maseti and Ntabanyane, 2017) and civil society organisations (Connolly, 2017). August is women's month in South Africa, providing a space for gender issues to feature prominently in the media (Moletsane, 2019). Such efforts are complemented by online campaigns such as the international \#MeToo (Mendes, Ringrose and Keller, 2018) and the local \#MenAreTrash (Samaga, 2017; Tanaka, 2019). The \#AmINext trended on Twitter after a specific incident catalysed public discussion. On $24 \mathrm{Au}-$ gust 2019, a 19-year-old university student was lured to a post office after hours, raped and killed by an employee (Independent Online, 2019). The ensuing online and social media outpour outlines two aspects relevant to our discussion, i.e. the discursive construction of the subjects involved and of gender-based violence.

The victim was a young and attractive member of the Black middle class and a student at a prestigious university. While comments such as "She is any of us. We feel helpless and scared"(@Hlehle_Lupindo,2 September 2019) imply a common condition of suffering on the basis of gender, decolonial scholars such as Dietze (2014) emphasise the importance of an intersectional approach, taking race, class and socio-economic background into account. Inequalities in (digital) media representation and government response are acknowledged by calls such as 'Can government, media and civil society give the same attention and love to other victims of sexual violence like they are giving to [her]. In this world if you are poor, your life does not matter' @,AdvoBarryRoux, 7 September 2019). The latter part of the tweet also illustrates how, in deSousa-Santos' (2012:53) words, 'Non-existence is produced whenever a certain entity is considered invisible, non-intelligible or discardable'. In the statement, 'But statistics show us that its the people we trust, the people who are close to us. rarely strangers [...] When last did $u$ see girls trending cos a blesser raped and killed them?' (@blaqdayimane, 18 October 2019). The reference to intimate relationships and "blessers" points towards the reality of many young women from a poor background who experience violence within a context of emotional dependency and/or economic deprivation (see Varjavandi, 2017). 
Online responses highlight other dimensions of difference while reaffirming a common experience of oppression. Examples such as 'Women get murdered literally everyday but people (Tweeps) get raged ONLY when it's a 'pretty', most of the time, light skinned women (sometimes with a Lil social influence) that gets to make the news'(@Amini_Kay, 8 September 2019) suggest the persistence of patriarchal and colonial prejudice, valuing women on account of their beauty in accordance with Western canons (see Bizela, 2016). In the tweet

\#bringNenehome thing has nothing do with the fact that [...] is popular or pretty or whatever you weirdos keep assuming. It has EVERYTHING to do with the fact that she is a young black woman and thus is extremely vulnerable. Any sane person would sympathize.

(@Libo_Ngwenya, 27 August 2019)

Ngwenya (2019) reaffirms a shared condition of suffering in relation to patriarchy and colonialism (see Christian, 1987) while appealing to "modern" concepts such as rationality which Mignolo (2007:451) regards as an 'engulfing and at the same time defensive and exclusionary' mean of emancipation.

Once identified, the perpetrator's house was burnt down by an angry mob and he was sentenced to life in jail. Conviction rates for rape and femicide are low and public/community justice is not uncommon in South Africa (see Singh, 2005; Comaroff, 2007). Some comments on Twitter advocated for the same to be done to the alleged perpetrator (@Rori_orr, 2019; @iloveretha, 2019; @zanelecele, 2019) with few critical reflections such as 'What if it turns out that, thats not his house?' (@be_kak,4 September 2019) and 'That for me, is another branch of mob justice' (@esihlel, 16 September 2019). References to the struggle against Apartheid were evident in calls for the practice of necklacing used by black communities to deal with spies and traitors (@Gaido Kb, 2019), in invoking divine justice reflecting the prominent role of churches as CSOs (@mabelanneko, 2019) and in calling for the antiApartheid strategy of 'making the country ungovernable' (@YMaqalekane, 2019) on Twitter. The latter was echoed in online media with provocative statements such as 'We must rage, we must give voice to our rage... we must march, we must burn things, we must express our collective rage. Men do all the time' (Thamm, 28 August 2019). The grewsome details of the case (see Nombembe, 15 August 2019) appear to justify such "suspension of ethics" (see Gordon, 2007) which Maldonado-Torres (2007) identifies as instrumental in the "naturalisation of the un-ethics of war" as an expression of the coloniality of being.

Besides advocating for extrajudicial punishment and public violence, arguably some of the worse enduring legacies of their shared troubled past, South Africans used digital media to open a conversation about reintroducing the death penalty abolished at the end of Apartheid. This provides an example of 'inter-subjectively produced 'public' reasons of those affected by 
particular issues' which Dahlberg (2007:48) identifies as a feature of online deliberative democracy. A petition on change.org (2019) highlights loss of faith in the effectiveness of the justice system (e.g. 'Enough is enough! We are being raped, killed and tortured every day and the perpetrators always roam free or get a lighter sentence. It's time to teach them a proper lesson and not allow them back into society!') as well as in political parties (@ Lukhanyo_Journ0, 2 September 2019), although some opposition parties took a favourable position. Somewhat paradoxically, the reintroduction of the death penalty was linked to the struggle against Apartheid as evident in claims such as 'This is not the South Africa our beloved struggle stalwarts fought for' (@GiftSmith_ZA,2 September 2019) and to human rights in a constitutional democracy as shown by @ThatoMo97 (2 September, 2019), who argues that 'The end of the death penalty by @,ConCourtSA was reasoned as a, cruel, inhuman and degrading punishment'. - The Constitution. Is rape \& murder not a, "cruel, inhuman and degrading punishment." FOR SIMPLY BEING A WOMAN IN SOUTH AFRICA?". The human rights discourse, critiqued by prominent decolonial scholars such as MaldonadoTorres (2017), is used by men to distance themselves from the issue as shown by some comments in online forums such as \#NotAllMen (see Hayes and Luther, 2018; Nicholas and Agius, 2018). As noted by Sanger (2019), there is a risk of reproducing colonial modes of thinking in racially and socioeconomically profiling criminals, thus supporting the construction of a barbaric, irrational, deviant "other" against whom anger can be legitimately expressed.

\section{Race and class}

South Africa's past of institutionalised racism and ethnic segregation is well documented (see Maylam, 2017). Despite attempts by the media to portray a non-racial society, race relations are still a contentious issue in political communication (see Dladla, 2017; Gottschalk, 2019). Videos documenting racist incidents are often shot with a mobile phone and posted on YouTube (Multimedia LIVE, 2017; SABC Digital News, 2018a, 2018b). Incidents of white middle-class South Africans posting racist remarks on social media attracted considerable public attention and resulted in convictions on the grounds of racism (Seleka and Grobler, 2020; Parez-Pena, 2018; Wicks, 2019). Beyond derogatory slur, several examples of racially motivated physical violence of whites against blacks (sometimes posted by the perpetrators themselves on YouTube) received media attention (see Keane, 2018).

On 30 November 2019, a Black traditional healer and his family were held hostage and he was eventually killed by a white farm owner, who was later shot by the intervening police (News24, 2019). A video posted on YouTube (LuiSpot, 2019) shows a white man shouting and terrorising a black family with a stick before budging the man to death. Anti-ANC, militaristic and messianic rants in the video are reminiscent of radical right-wing politics 
and religious fervour associated with Afrikaner nationalism under Apartheid (see Patterson, 1977; Vuuren, 2005). News articles available online (The Citizen, 2019; SABC Digital News, 2019) as well as many user comments attributed the attack to mental instability consistent with attempts to downplay racism (particularly by white Afrikaners) in the media (see Wasserman, 2010). In fact, comments such as 'This man was clearly mentally ill. Such a sad situation. Now this whole country is gonna hate on each other again cause of this' (Lisa Marie, 2019) highlight the potential for this incident to be politicised and re-ignite racial tensions. Resentment on the part of some users is evident in replies to the latter comment, such as 'So a white kills a Blackman like these and you blame mental sicknss, I think you are sick yourself' (CS DR, 2019), 'Maybe you are sick together, how can u come here defend a white criminal=' (Pumelele Mahlombe, 2019) as well as comments to related videos (Multimedia LIVE, 2019), such as 'My question is, if it was mental health illness why did he not chose one of his white friend???' (Peter Ncube, 2019). By contesting modern individualistic models of mental illness, coloniality of disability (Dirth and Adams, 2019) provides a tool to "normalise" and, at the same time, contextualise deviant behaviour such as the one depicted in the video within socio-historical processes. On the one hand, this suggests the use of mental illness to explain violent and irrational behaviour by a member of the "civilised" group, a practice seldom employed with colonised subjects. On the other hand, it exposes the reduction of the perpetrator to a member of a subaltern group (the disabled) possibly as an attempt to preserve the link between moral superiority and racial identity.

This incident is significant in terms of the mediatised construction of the subjects involved as well as its timing. The victim was a traditional healer, suggesting an association with superstition, backwardness and inferiority. Santos (2012:52) notes how the logic of linear time 'produces non-existence by describing as backward whatever is asymmetrical vis-à-vis whatever is declared forward'. Some users like Rechardo Fritz (2019) even believed that eradicating such backwardness was the motive, as suggested by the claim that 'people recording killings of Black people because they are traditional HEALERS...that is not on!', the perpetrator was allegedly his friend and a trainee sangoma (i.e. traditional healer) himself. Emphasis on this point in the media (often alongside allegations of a history of violent behaviour) (Dayimani, 2019; Head, 2019a, 2019b) supports the "othering" process of subalternisation noted above with respect to disability and expressed by comments such as 'He was a white Sangoma (witch doctor) and affiliated with the ANC! Definitely not a FARMER, typical african propaganda like usual!' (AQW, 2019) and '[the perpetrator] is NOT white' (lauqe rianne, 2019). Replies to the latter comment, i.e. 'may he rest in peace, may all white racists die a horrible death' (Z D, 2019), reaffirm a radical and violent stance against the perpetrator as representative of all colonising subjects. The video was published shortly after South Africa won the 2019 Rugby World Cup, amidst racial controversies (Kiewit, 2019) motivated by the long-standing 
association of rugby with white nationalism (see Tembo, 2019). Comments such as 'EFF highlighted that this cook wore a springboks jersey..really... what is the end goal in that though' (C2de G, 2019) point to a possible indication of racism. This point was picked up by opposition politicians who decried the relatively limited coverage of the story by news outlets as an example of white privilege (Head, 2019a, 2019b) in the official statement:

All major news outlets should be leading with this anti-black farm murder committed by a white, racist, Springbok t-shirt-wearing man. People will find this hard to accept, they will live in denial and the false euphoria created by the very politics of the Springbok t-shirt worn by the anti-black perpetrator.

(Ndlozi, 2019)

The reference to a farm murder above resonates with a narrative of white genocide which gained media coverage nationally and internationally, as shown by comments such as '@CS DR blacks go around slaughtering white farmers all the time. Your silence about it is deafening' [reply to a comment in the YouTube video]. While most victims of violent crime are Black (see Bearak, 2010), violence against whites and in particular farmers gained national and international resonance (Ward, 2018; Williams, 2018; vpro documentary, 2019). Comments to a right-wing documentary Farmlands provide examples of racism 'In 20 years [Blacks] they're going to be starving to death because of their policies. Somehow they'll find a way to blame white people for that too' (AdamIowa88, 2019) and praise for the Apartheid and colonial past as in 'South Africa is now ten times worse than it was back in the 1980s before the end of aparthied' (Angus Meigh, 2019) and '@Fatou soumare You would be nothing without white people. What did you do in africa? You didn't even have a written language or nothing' (St. Simon of Trent, 2019) which resonate with a tweet by an opposition politician which sparked considerable public debate (Nkanjeni, 2019) and with Mignolo's (2007:453) assertion that 'modernity appears when Europe affirms itself as the "center" of a World History that it inaugurates'. Drawing on the powerful discourse of minority and human rights, the CSO Afriforum lobbied for the recognition of refugee status for farmers migrating from South Africa to Australia (Taylor, 2018). Consistent with an othering strategy, Afriforum warned against referring to the perpetrator in the incident discussed above as a "farmer" (The Citizen, 2019).

Farmlands are sites of intense ideological struggle as well as mediatise physical violence. For historical reasons, race is inextricably linked to class in South Africa, with unequal distribution of arable land as a case in point (see Keane, 2018). In the aftermath of the incident discussed above, the opposition party EFF organised the occupation of the perpetrator's farm with the intention of converting it into a preschool (The Citizen, 2019). The old South African flag, allegedly found on the premises, is banned from 
gratuitous public display as a symbol of white supremacy and racial oppression (Bernstein and Lopes, 2019), fuelling calls for the expropriation of the property without compensation (Baloyi, 2020). While actual land reform yielded mixed results, the prospect of taking land away from white farmers perceived to have benefitted unfairly from past policies holds political appeal as an instrument of social justice for some, while fuelling fears of reverse racism for others.

\section{Reflections and conclusions}

The two examples discussed in this chapter are by no means representative of the whole spectrum of issues pertaining to gender, race and/or class in South Africa. Stories of corrective rape of lesbian black women, xenophobic attacks against foreigners from other African countries, police brutality against street vendors, etc. may provide a better representation of the lived experiences of marginalised subjects. However, the very resonance of the two incidents with a number of ongoing public discussions can be read as an indication of coloniality. These two stories provide intelligible representations of rape and murder within a Western patriarchal and colonial trope (e.g. an older male stranger deceiving and violently assaulting a younger unsuspecting woman, a deranged white man budging a meek black friend to death). Public outrage about such incidents diverts attention from less visible but more pervasive aspects of domination, such as institutional sexism and racism, and from more localised (but not less real) conditions of oppression. By constructing the perpetrators as deviant outcasts, online discussions preserve rather than challenge hierarchical structures and the underlying dichotomies (men/ women, black/white, rich/poor), as well as legitimising violence. Radical positions such as burning rapists alive or killing white racists do not represent epistemic disobedience, but rather compliance with a logic of suspended ethics central to the colonial project. Aspects of patriarchal and colonial discourses such as victim blaming, though present in both cases, were not considered here as they are not particularly relevant to political communication.

\section{References}

@ AdvoBarryRoux. (2019). Can government, media and civil society give the same attention and love to other victims of sexual violence like they are giving to [...]. [Twitter]. 7 September. [Accessed 12/04/2020]. Available from: https://twitter.com/ AdvoBarryRoux/status/1170286282473390081

@,Amini_Kay. (2019). Women get murdered literally everyday but people(Tweeps) get raged ONLY when it's a "pretty" [...]. [Twitter] 8 September. [Accessed 12/04/2020]. Available from: https://twitter.com/Amini_Kay/status/1170649750082863104

@be_kak. (2019). What if it turns out that, thats not his house? [Twitter]. 4 September. [Accessed 12/04/2020]. Available from: https://twitter.com/be_kak/ status/1169155614959947778 
@ blaqdayimane. (2019). But statistics show us that its the people we trust, the people who are close to us. rarely strangers [...]. [Twitter]. 18 October. [Accessed 12/04/2020]. Available from: https://twitter.com/blaqdayimane/status/11851022 88681132032

@esihlel. (2019). That for me, is another branch of mob justice. [Twitter]. 16 September. [Accessed 12/04/2020]. Available from: https://twitter.com/EsihleL/ status/1173361638919069696

@Gaido_Kb. (2019). Now he must be necklaced. [Twitter]. 3 September. [Accessed 12/04/2020]. Available from: https://twitter.com/Gaido_Kb/status/116896 9244417155073

@GiftSmith_ZA. (2019). Death penalty should be re-instated. Women are living in fear. [Twitter]. 2 September. [Accessed 12/04/2020]. Available at: https://twitter. com/GiftSmith_ZA/status/1168500347914072065

@ Hlehle_Lupindo. (2019). She is any of us. We feel helpless and scared [Twitter]. 2 September. [Accessed 12/04/2020]. Available from: https://twitter.com/ Hlehle_Lupindo/status/1168562917572317184

@iloverethe. (2019). Luyanda Botha's house is currently being burnt to ashes by abantu base Khayelitsha [...]. [Twitter]. 3 September. [Accessed 12/04/2020]. Available from: https://twitter.com/iloveretha/status/1168940555360976896

@Libo_Ngwenya. (2019). It has EVERYTHING to do with the fact that she is a young black woman and thus is extremely vulnerable [...]. [Twitter]. 27 August. [Accessed 12/04/2020]. Available from: https://twitter.com/Libo_Ngwenya/ status/1166381160387272704

@_Lukhanyo_Journ0. (2019). What kinda society is SouthAfrica? NONE of this country's political parties have the death penalty in their policies [...]. [Twitter]. 2 September. [Accessed 12/04/2020]. Available from: https://twitter.com/ Lukhanyo_Journ0/status/1168579372758065154

@ mabelanneko. (2019). Yall are doing the Lord's work. [Twitter] 3 September. [Accessed 12/04/2020]. Available from: https://twitter.com/mabelanneko/ status/1168963422878347267

@ Rori_orr. (2019). He should've been inside. [Twitter]. 3 September. [Accessed 12/04/2020]. Available from: https://twitter.com/Rori_orr/status/11689 47005596602368

@ ThatoMo97. (2019). The end of the death penalty by @ConCourtSA was reasoned as a, "cruel, inhuman and degrading punishment" [...]. [Twitter]. 2 September. [Accessed 12/04/2020]. Available from: https://twitter.com/ThatoMo97/ status/1168564801771098113

@)YMaqalekane. (2019). We must bring back the death penalty and to do so we as citizens must shut down South Africa! [Twitter]. 3 September. [Accessed 12/04/2020]. Available from: https://twitter.com/YMaqalekane/status/1168504326551158784

(a)zanelecele. (2019). They should locked the doors first and burned him alive. [Twitter]. 3 September. [Accessed 12/04/2020]. Available from: https://twitter.com/ zanelecele/status/1168965191771537410

AdamIowa88. (2019) Re: FARMLANDS (2018) | Official Documentary. [Video file]. Retrieved from https://www.youtube.com/watch?v=a_bDc7FfItk\&t=16s

Akinbobola, Y. (2015). Theorising the African digital public sphere: A West African odyssey. African Journalism Studies, 36(4), pp. 47-65.

AQW. (2019) Re: SA reacts to Anele Hoyana's murder. [Video file]. Retrieved from https://www.youtube.com/watch?v=gP1GFyg3_fI 
Arora, P. (2016). Bottom of the data pyramid: Big data and the global south. International Journal of Communication, 10(19), pp. 81-99.

Baloyi, T. (2020). 'Land expropriation: Deadline to amend Constitution extended... again' The South African, 7 March 2020. Available at: https://www. thesouthafrican.com/news/land-expropriation-deadline-extended-may-2020/ [Accessed 12/04/2020]

Bearak, B., 2009. Constant fear and mob rule in South Africa slum. New York Times, 29, June 2009. Available at: https://www.nytimes.com/2009/06/30/world/ africa/30safrica.html [Accessed 12/04/2020]

Bernstein, D. and Lopes, R. (2019). "Never Again"-the old South African flag case: Spotlight on pro bono. Without Prejudice, 19(10), pp. 14-15.

Bizela, S. (2016). Post-Fanonian or not? The 'yellow bone' factor and re-writing blackness in popular culture. WritingThreeSixty, 2(2), pp. 27-42.

Bruce, D. (2002). Police brutality in South Africa. From the report Police Brutality in Southern Africa-A Human Rights Perspective, edited by N. Mwanajiti, P. Mhlanga, M. Sifuniso, Y. Nachali-Kambikambi, M. Muuba and M. Mwananyanda. Inter-African Network for Human Rights and Development (Afronet). Available at: https://www.csvr.org.za/docs/policing/policebrutality.pdf

Buiten, D. and Naidoo, K. (2016). Framing the problem of rape in South Africa: Gender, race, class and state histories. Current Sociology, 64(4), pp. 535-550.

C2de G. (2019) Re: SA reacts to Anele Hoyana's murder. [Video file].Retrieved from https://www.youtube.com/watch?v=gPlGFyg3_fI

Change.org. (2020). Bring back the death sentence in SA for crimes against women. Retrieved online from: https://www.change.org/p/south-african-governmentbring-back-the-death-sentence-in-sa-for-crimes-against-women

Chiumbu, S. (2016). Media, race and capital: A decolonial analysis of representation of miners' strikes in South Africa. African Studies, 75(3), pp. 417-435.

Christie, D. J., Wagner, R. V., and Winter, D. A. (Eds.). (2001). Peace, Conflict, and Violence: Peace Psychology for the 21st Century. Englewood Cliffs, New Jersey: Prentice-Hall.

Chunylall, R. (2016). \# Democracy: A case study of social media use amongst members of the public sphere during the 2014 South African general election (Doctoral dissertation).

Citizen Reporter. (2019). 'EFF invade Fritz 'Majeke' Joubert's smallholding, 'discover old SA flag”' The Citizen, 4 December 2019. Available at: https://citizen.co.za/ news/south-africa/crime/2214632/eff-invade-fritz-majeke-jouberts-smallholdingdiscover-old-sa-flag/ [Accessed 12/04/2020]

Comaroff, J. and Comaroff, J. (2007). Popular justice in the new South Africa: Policing the boundaries of freedom. Legitimacy and criminal justice: International perspectives. New York: Russell Sage Foundation, pp. 215-238.

Connolly, S. (2017). Assessing the successes of and challenges facing civil society organizations in South Africa, in influencing gender-based violence policy. Independent Study Project (ISP) collection. Available from: https://digitalcollections. sit.edu/isp_collection/2697

Couldry, N. and Mejias, U. A. (2019). Data colonialism: Rethinking big data's relation to the contemporary subject. Television \& New Media, 20(4), pp. 336-349.

CS DR. (2019) Re: Anele Hoyana murder | Busisiwe Jemsana-Mantashe speaks to SAPS officials. [Video file].Retrieved from https://www.youtube.com/watch? $v=$ aOWI2VCNVuk 
Dahlberg, L. (2007). The Internet, deliberative democracy, and power: Radicalizing the public sphere. International Journal of Media \& Cultural Politics, 3(1), pp. $47-64$.

Dayimani, M. (2019). 'Sangoma killer Fritz Joubert was fired from police 'after too many deaths', Timeslive, 5 December 2019. Available at: https://www.timeslive. co.za/news/south-africa/2019-12-05-sangoma-killer-fritz-joubert-was-fired-frompolice-after-too-many-deaths/ [Accessed 13/04/2020]

Dean, J. (2005). Communicative capitalism: Circulation and the foreclosure of politics. Cultural Politics, 1(1), pp. 51-74.

Dietze, G. (2014). Decolonizing gender-Gendering decolonial theory: Crosscurrents and archaeologies. In Decoloniality, Postcoloniality, Black Critique: Joints and Fissures, 245-69.

Dirth, T. P. and Adams, G. A. (2019). Decolonial theory and disability studies: On the modernity/coloniality of ability. Journal of Social and Political Psychology, 7(1), pp. 260-289.

Dladla, N. (2017). Racism and the marginality of African philosophy in South Africa. Phronimon, 18(1), pp. 204-231.

Dlamini, Z., Malinga, L., Masiane, T. and Tshiololi, M. (2018). Social media advocacy in the\# MustFall campaigns in South Africa. In A. Josang (Ed). ECCWS 2018 17th European Conference on Cyber Warfare and Security V2 (p. 120). Oslo: Academic Conferences and publishing limited.

E-International Relations. (2017). Interview_-Walter Mignolo Part 2. 21 January 2017. Available at: https://www.e-ir.info/2017/01/21/interview-walter-mignolopart-2key-concepts/

Etheridge, J. (2019). 'East London man who killed friend and held his children hostage shot dead on farm', News24, 02 December 2019. Available at: https://www. news24.com/SouthAfrica/News/east-london-man-who-killed-friend-and-heldhis-children-hostage-shot-dead-on-farm-20191202 [Accessed 13/04/2020]

Fritz. (2019) Re: SA reacts to Anele Hoyana's murder. [Video file].Retrieved from https://www.youtube.com/watch?v=gP1GFyg3_fI

Glenn, I. and Mattes, R. (2011). Political communication in post-apartheid South Africa. The Sage Handbook of Political Communication. London: Sage Publications.

Gordon, L. (2007). Problematic People and Epistemic Decolonization. Postcolonialism and Political Theory (p. 121).

Gottschalk, K. (2019). 'Race still colours South Africa's politics 25 years after apartheid's end' The Conversation, 1 May 2019. Available at: https://theconversation. com/race-still-colours-south-africas-politics-25-years-after-apartheidsend-115735 [Accessed 12/04/2020]

Graham, L. (2020). 'Pandemic underscores gross inequalities in South Africa, and the need to fix them' The Conversation Africa, 5 April 2020. Available at: https:// theconversation.com/pandemic-underscores-gross-inequalities-in-south-africaand-the-need-to-fix-them-135070 [Accessed 12/04/2020]

Hayes, R. M., \& Luther, K. (2018). \# Notallmen: Media and crime victimization. In \# Crime (pp. 123-151). Cham: Palgrave Macmillan.

Head, T. (2019a). 'Fritz Joubert: Criminal history of "sangoma killer" surfaces' The South African, 5 December 2019. Available at: https://www.thesouthafrican.com/ news/off beat/fritz-joubert-criminal-past-court-dates-former-cop/ [Accessed $13 / 04 / 2020]$ 
Head, T. (2019b). 'Fritz Joubert: EFF blame "white privilege" after man murders sangoma' The South African, 2 December 2019. Available at: https://www. thesouthafrican.com/news/who-is-fritz-joubert-murder-anele-eff-reactionmalema/ [Accessed 13/04/2020]

Horwitz, F. M. and Jain, H. (2011). An assessment of employment equity and broad based black economic empowerment developments in South Africa. Equality, Diversity and Inclusion: An International Journal, 30(4), pp. 297-317.

Independent Online. (2019). '\#AmINext trends as SA reels after Uyinene Mrwetyana's murder' Independent Online, 2 September 2019. Available at: https:// www.iol.co.za/news/south-africa/western-cape/aminext-trends-as-sa-reels-afteruyinene-mrwetyanas-murder-31743016 [Accessed 12/04/2020]

Jewkes, R., Levin, J. and Penn-Kekana, L. (2002). Risk factors for domestic violence: findings from a South African cross-sectional study. Social Science \& Medicine, 55(9), pp. 1603-1617.

Keane, F. (2018). 'South Africa's 'toxic' race relations' BBC, 18 December 2018. Available at: https://www.bbc.com/news/world-africa-46071479 [Accessed on $11 / 04 / 2020]$

Kiewit, L. (2019). 'Racism stops rugby's try at uniting South Africa' Mail \& Guardian, 10 October 2019. Available at: https://mg.co.za/article/2019-10-10-racismstops-rugbys-try-at-uniting-south-africa/ [Accessed 13/04/2020]

Lauren Southern. (2018). FARMLANDS (2018) | Official Documentary. [Online Video). Available at: https://www.youtube.com/watch?v=a_bDc7FfItk\& feature=youtu.be [Accessed 12/03/2020]

LuiSpot. (2019). Fritz Joubert Films the murder of Anele Hoyana. [Online Video]. Available at: https://www.youtube.com/watch?v=dmtyBZTqugk [Accessed 13/04/2020]

Mahlomber. (2019) Re: Anele Hoyana murder | Busisiwe Jemsana-Mantashe speaks to SAPS officials. [Video file].Retrieved from https://www.youtube.com/ watch? $\mathrm{v}=\mathrm{aOWI} 2 \mathrm{VCNVuk}$

Maldonado-Torres, N. (2007). On the coloniality of being: Contributions to the development of a concept. Cultural Studies, 21(2-3), pp. 240-270.

Maldonado-Torres, N. (2017). On the coloniality of human rights. Revista Critica de Ciências Sociais, 114, pp. 117-136.

Manderson, L. and Levine, S. (2020). COVID-19, Risk, Fear, and Fall-Out. Medical Anthropology, 39(5), pp. 367-370.

Marie. (2019) Re: Anele Hoyana murder | Busisiwe Jemsana-Mantashe speaks to SAPS officials. [Video file].Retrieved from https://www.youtube.com/ watch? $\mathrm{v}=\mathrm{aOWI} 2 \mathrm{VCNVuk}$

Maylam, P. (2017). South Africa's racial past: The history and historiography of racism, segregation, and apartheid. London: Routledge.

Mbembe, A. (2001). On the Postcolony. Berkeley: University of California Press.

Meigh. (2019) Re: FARMLANDS (2018) | Official Documentary. [Video file].Retrieved from https://www.youtube.com/watch?v=a_bDc7FfItk\&t=16s

Mendes, K., Ringrose, J. and Keller, J. (2018). \# MeToo and the promise and pitfalls of challenging rape culture through digital feminist activism. European Journal of Women's Studies, 25(2), pp. 236-246.

Meyiwa, T., Williamson, C., Maseti, T. and Ntabanyane, G. M. (2017). A twentyyear review of policy landscape for gender-based violence in South Africa. Gender and Behaviour, 15(2), pp. 8607-8617. 
Mignolo, W. D. (2007). Delinking: The rhetoric of modernity, the logic of coloniality and the grammar of de-coloniality. Cultural Studies, 21(2-3), pp. 449-514.

Moletsane, R. (2018). "Stop the war on women's bodies": Facilitating a girl-led march against sexual violence in a rural community in South Africa. Studies in Social Justice, 12(2), pp. 235-250.

Morozov, E. (2011). The net delusion: How not to liberate the world. London: Penguin.

Multimedia LIVE. (2017). Cape Town driver attacked in fit of road rage. [Online Video]. Available at: https://www.youtube.com/watch?v=DL0Zj692Lq4 [Accessed 13/04/2020]

Multimedia LIVE. (2019). SA reacts to Anele Hoyana's murder. [Online Video]. Available at: https://www.youtube.com/watch?v=gP1GFyg3_fI [Accessed 13/04/2020]

Ncube. (2019) Re: SA reacts to Anele Hoyana's murder. [Video file].Retrieved from https://www.youtube.com/watch?v=gP1GFyg3_fI

Ndlovu, M. (2018). Coloniality of knowledge and the challenge of creating African futures. Ufahamu: A Journal of African Studies, 40(2).

Ndlozi, M. (2019). 'Brutal and racist murder of Anele Hoyana by white farmer EFF', PoliticsWeb, 2 December 2019. Available at: https://www.politicsweb.co. za/news-and-analysis/brutal-and-racist-murder-of-anele-hoyana-by-white[Accessed 13/04/2020]

News24 Wire. (2019). "Fritz was not a stranger to us, he was a neighbour of 15 years' Anele Hoyana's family', The Citizen, 4 December 2019. Available at: https:// citizen.co.za/news/south-africa/crime/2214379/fritz-was-not-a-stranger-to-us-hewas-a-neighbour-of-15-years-anele-hoyanas-family/ [Accessed 13/04/2020]

Nicholas, L., \& Agius, C. (2018). \# Notallmen,\# Menenism, Manospheres and Unsafe Spaces: Overt and Subtle Masculinism in Anti-"PC" Discourse. In L. Nicholas and C, Agius (Eds). The Persistence of Global Masculinism (pp. 3159). Cham: Palgrave Macmillan.

Nkanjeni, U. (2019). 'Helen Zille tweets her way into hot water, again and again and again and again' Timeslive, 23 May 2019. Available at: https://www.timeslive. co.za/politics/2019-05-23-helen-zille-tweets-her-way-into-hot-water-again-andagain-and-again-and-again/ [Accessed 13/03/2020]

Nombembe, P. (2019). 'IN HIS OWN WORDS | Luyanda Botha: 'This is how I killed Uyinene'. Sunday Times, 15 November 2019. Available at: https://www.timeslive. co.za/news/south-africa/2019-11-15-in-his-own-words-luyanda-botha-this-ishow-i-killed-uyinene/ [Accessed 12/04/2020]

Parez-Pena, R. (2018). 'Woman becomes first South African imprisoned for racist speech video', New York Times, 28 March 2018. Available at: https://www. nytimes.com/2018/03/28/world/europe/south-africa-racist-speech.html [Accessed 13/04/2020]

Passada, M. N. M. (2019). Discourses analysis by a decolonial perspective. In L, Suciu (Ed). Advances in Discourse Analysis. Available from: https://www. intechopen.com/books/advances-in-discourse-analysis/discourses-analysis-bya-decolonial-perspective

Patterson, S. (1977). The white Africans. African Affairs, 76 (302), pp. 108-111.

Quijano, A. (2000). Coloniality of power and Eurocentrism in Latin America. International Sociology, 15(2), pp. 215-232.

Resende, V. D. M. (2018). Decolonizing critical discourse studies: For a Latin American perspective. Critical Discourse Studies, 18(1), pp. 1-17. 
Rianne. (2019) Re: SA reacts to Anele Hoyana's murder. [Video file].Retrieved from https://www.youtube.com/watch?v=gP1GFyg3_fI

SABC Digital News. (2018a). Reaction to Adam Catzavelos racist rant: Adv. Priscilla Jana. [Online Video]. Available at: https://www.youtube.com/watch?v= cc3MOIuSmKc [Accessed 13/04/2020]

SABC Digital News. (2018b). SAHRC investigates Adam Catzavelos racist rant. [Online Video]. Available at: https://www.youtube.com/watch? $\mathrm{v}=\mathrm{mOjNyiuvUzw}$ [Accessed 13/04/2020]

SABC Digital News. (2019). Anele Hoyana murder | Busisiwe Jemsana-Mantashe speaks to SAPS officials. [Online Video]. Available at: https://www.youtube.com/ watch? $\mathrm{v}=\mathrm{aOWI} 2 \mathrm{VCNVuk}$ [Accessed 13/04/2020]

Salawu, A. ed. (2018). African language digital media and communication. Routledge.

Samaga, R. (2017). 'The real story behind \#menaretrash, South Africa's response to domestic violence' OK Africa, 15 May 2017. Available at: https://www. okayafrica.com/real-story-behind-menaretrash-south-africas-viral-hashtag/ [Accessed 13/04/2020]

Sanger, N. (2019). A matter of race and class: Notes on populist feminism in theorising from the South. Agenda, 33(3), pp. 70-73.

Santos, B. D. S. (2012). Public sphere and epistemologies of the South. Africa Development, 37(1), pp. 43-67.

Santos, B. D. S. (2016). Epistemologies of the South and the future. From the European South: a transdisciplinary. Journal of Postcolonial Humanities, 1, pp. 17-29.

Seleka, N. and Grobbler. (2020). 'Adam Catzavelos gets suspended sentence for k-word rant', News24, 28 February 2020. Available at: https://www.news24. com/SouthAfrica/News/breaking-adam-catzavelos-handed-down-r50-000suspended-sentence-for-k-word-video-20200228 [Accessed 13/04/2020]

Singh, D. (2005). Resorting to community justice when state policing fails: South Africa. Acta Criminologica: African Journal of Criminology \& Victimology, 18(3), pp. 43-50.

Soudien, C. (2010). The reconstitution of privilege: Integration in former white schools in South Africa. Journal of Social Issues, 66(2), pp. 352-366.

St. Simon of Trent. (2019) Re: FARMLANDS (2018) | Official Documentary. [Video file].Retrieved from https://www.youtube.com/watch? $v=a \_b D c 7 F f I t k \& t=16 \mathrm{~s}$

Statcounter. (2020). Social Media Stats South Africa. Available at: https://gs. statcounter.com/social-media-stats/all/south-africa [Accessed 12/04/2020]

Statista. (2020). Digital population in South Africa as of January 2020. Available at: https://www.statista.com/statistics/685134/south-africa-digital-population/ [Accessed 12/04/2020]

Swartz, S., Arogundade, E. and Davis, D. (2014). Unpacking (white) privilege in a South African university classroom: A neglected element in multicultural educational contexts. Journal of Moral Education, 43(3), pp. 345-361.

Tanaka, S. (2019). MEN ARE TRASH. Sister Namibia, 31(3), pp. 26-28.

Taylor, A. (2018). 'Australia looks into resettling white South African farmers who say they are persecuted' Washington Post, 16 March 2018. Available at: https:// www.washingtonpost.com/news/worldviews/wp/2018/03/16/australia-looks-intoresettling-white-south-african-farmers-who-say-they-are-persecuted/ [Accessed $12 / 04 / 2020]$

Tembo, N. M. (2019). The decolonial Mandela: Peace, justice and the politics of life by Sabelo Ndlovu-Gatsheni. Biography, 42(2), pp. 426-430. 
Thamm, M. (2019). 'Unstoppable horror - What are we to do with the rage' Daily Maverick, 28 August 2019. Available at: https://www.dailymaverick. co.za/article/2019-08-28-unstoppable-horror-what-are-we-to-do-with-the-rage/ [Accessed 12/04/2020]

Varjavandi, R. (2017). \# Blessers Must Fall: Youth-led participatory action research and photo story creation on teenage pregnancy, transactional sex and genderbased violence. Agenda, 31(2), pp. 87-98.

Vpro Documentary. (2019). White farmers killings in Africa | VPRO Documentary. [Online Video]. Available at: https://www.youtube.com/watch?v=b-Ubvkep0jQ [Accessed 12/04/2020]

Vuuren, W. V. (2005). Ideologies of racial nationalism: The method in their madness. Politikon, 32(1), pp. 59-81.

Walton, M., \& Leukes, P. (2013). Prepaid social media and mobile discourse in South Africa. Journal of African Media Studies, 5(2), pp. 149-167.

Ward, J. (2018). 'The dangerous myth of 'white genocide' in South Africa' Southern Poverty Law Center, 23 August 2018. Available at: https://www.splcenter.org/ hatewatch/2018/08/23/dangerous-myth-white-genocide-south-africa [Accessed 12/04/2020]

Wasserman, H. (2010). 'We're not like that': Denial of racism in the Afrikaans press in South Africa. Communication: South African Journal for Communication Theory and Research, 36(1), pp. 20-36.

Wasserman, H. (2011). Mobile phones, popular media, and everyday African democracy: Transmissions and transgressions. Popular Communication, 9(2), pp. $146-158$.

We are Social. (2020). DIGITAL 2020: SOUTH AFRICA. Available at: https:// datareportal.com/digital-in-south-africa [Accessed 12/04/2020]

Wicks, J. (2019). 'Penny sparrow dies', Timeslive, 25 July 2019. Available at: https://www.timeslive.co.za/news/south-africa/2019-07-25-penny-sparrow-dies/ [Accessed 13/04/2020]

Wilkinson, K. (2017). 'FACTSHEET: Statistics on farm attacks and murders in South Africa' Africa Check, 8 May 2017. Available at: https://africacheck.org/ factsheets/factsheet-statistics-farm-attacks-murders-sa/ [Accessed 12/04/2020]

Willems, W. (2012). Interrogating public sphere and popular culture as theoretical concepts on their value in African studies. Africa Development, 37(1), pp. 11-26.

Williams, J. (2018). 'Trump's tweet echoing white nationalist propaganda about South African farmers, explained' Vox, 23 August 2018. Available at: https:// www.vox.com/policy-and-politics/2018/8/23/17772056/south-africa-trump-tweetafriforum-white-farmers-violence [Accessed 12/04/2020]

Z D. (2019) Re: SA reacts to Anele Hoyana's murder. [Video file].Retrieved from https://www.youtube.com/watch?v=gP1GFyg3_fI 